\title{
POCHWALY NA CZEŚĆ PANA WRAZ Z CUDEM, KTÓRY WYDARZYŁ SIE W KRAJU EDUÓW (Laudes Domini cum miraculo quod accidit in Aeduico, CPL 1386)
}

\section{Anonimowy galijski poemat z IV wieku po Chrystusie}

\section{WSTĘP}

Jednym $\mathrm{z}$ najstarszych zachowanych do naszych czasów zabytków wczesnochrześcijańskiej poezji lacińskiej jest pochodzący z IV wieku poemat Laudes Domini. Ze względu na podobieństwa stylistyczne przypisywano go dawniej m.in. Paulinowi z Noli, a zwłaszcza, ze względu na istniejące podobieństwa sformułowań, Juwenkusowi ${ }^{1}$, jednak faktyczne autorstwo pozostaje wciąż nieustalone. Jest to niewątpliwie jeden z najwcześniejszych przykładów poezji chrześcijańskiej z okresu, w którym imperium pod rządami Konstantyna Wielkiego ulega powolnej chrystianizacji, ale wpływy pogańskie są jeszcze bardzo silne, a publiczność literacka mocno osadzona w świecie tradycyjnego wykształcenia. Stąd autor poematu, niewątpliwie dobrze obeznany z klasyczną poezją rzymską, odwołuje się wielokrotnie do wybitnych jej przedstawicieli: Wergiliusza, Horacego, Owidiusza i Lukrecjusza, korzysta jednak również z dorobku poetów chrześcijańskich, głównie współczesnego mu Juwenkusa oraz, naturalnie, z Pisma Swiętego. W przeciwieństwie jednak do autorów z nieco późniejszego okresu centonów (m.in. Proby), z umiarem posługuje się cytatami, dostosowując je do potrzeb konkretnego utworu i świata chrześcijańskich pojęć.

Na podstawie argumentów wewnętrznych (czystość języka, doskonała znajomość metryki i literatury klasycznej) można wnioskować, iż autor Laudes Domini był najprawdopodobniej wykształconym przedstawicielem wyższych warstw zromanizowanej społeczności galijskiej, zamieszkującej teren miasta Augustodunum w prowincji Galia Lugdunensis, dzisiejszego Autun w środko-

${ }^{1}$ Zbieżności z Juwenkusem tłumaczy się zasadniczo wspólnymi źródłami: Pismem Świętym i twórczością Wergiliusza. Podstawowym zamiarem Juwenkusa w dziele Evangeliorum libri było przede wszystkim streszczenie w formie poetyckiej zawartości Ewangelii. Prócz tego, o ile u Juwenkusa na plan pierwszy wysuwa się sprawność poetyckiego obrazowania, o tyle autor Laudes jest uważany za sprawnego wersyfikatora, por. P. van der Weijden, Laudes Domini, Text, vertaling en commentar, Amsterdam 1967, 20-25. 
wej Francji. Założone w 10 r. przed Chr. przez cesarza Augusta przeżywało ono rozkwit w pierwszych dwóch stuleciach po Chrystusie, będąc wówczas zarówno stolicą plemienia Eduów, jak również ważnym ośrodkiem naukowym, do którego ściągała po wykształcenie młodzież z całej Galii ${ }^{2}$. Istniała tu sławna szkoła retoryczna tzw. schola Maeniana, której wychowankiem z dużym prawdopodobieństwem mógł być także autor Laudes Domini. Jako siedziba prefekta rzymskiego Augustodunum należało do najważniejszych miast Galii. Miasto było umocnione (zachowała się do naszych czasów dawna brama miejska zw. Porte Saint-André) i posiadało wiele wspaniałych budowli, m.in. kapitol ze świątynią Minerwy, sanktuarium Apollona z wyrocznią, świętym gajem i źródłem, a także amfiteatr zaliczany do największych na obszarze Galii. Miasto, zniszczone w 269 r. przez wojska Tetrikusa, rodzimego pretendenta do tronu cesarskiego, a później przez bandy zubożałych chłopów zwanych bagaudami, popadło $\mathrm{w} 2$ poł. III wieku $\mathrm{w}$ ruinę: budowle znalazły się $\mathrm{w}$ gruzach, pola uprawne leżały odłogiem, a winnice zostały wycięte. Odbudowane dopiero u schyłku III w. przez cesarza Konstancjusza Chlorusa (za co pochodzący z Augustodunum retor Eumeniusz dziękował cesarzowi w r. 298 w mowie De scholis restituendis oratio, prosząc jednocześnie o przeznaczenie środków na odnowienie Maeniany ${ }^{3}$ ), zyskało również znaczne ulgi podatkowe ze strony jego syna, Konstantyna Wielkiego, który odwiedził miasto w 311 r. (nosiło ono wówczas nazwę Flavia Aeduorum) ${ }^{4}$.

Chrześcijaństwo dotarło do Autun prawdopodobnie dosyć wcześnie. Pierwotna gmina ulokowała się nieco na uboczu, w odległości kilometra od rzymskiego miasta, na wzgórzu Saint-Pierre-de-Lestrier (lac. Sanctus Petrus de Strata), rozciągając się wokół zespołu cmentarnego zw. polyandres (złożonego z cmentarzy Saint Pierre l'Etrier, Champs-des-Urnes, Champs-Saint Roch i Bois-Saint Jean), funkcjonującego jeszcze w XVIII wieku. Na jego terenie znaleziono relikty wczesnochrześcijańskiej sztuki sepulkralnej ${ }^{5}$. Wg późnego, na wpół legendarnego przekazu Passio sancti Symphoriani z V wieku, św. Polikarp w obliczu prześladowań za Septymiusza Sewera w III wieku miał przydzielić sw. Ireneuszowi dwóch kapłanów i diakona (święci: Benignus, Andochius i Thyrsus), którzy udali się do Autun i, z wyjątkiem pierwszego $\mathrm{z}$ nich, już tam pozostali. Prawdopodobnie jednak miasto nie było jeszcze wówczas siedzibą biskupa. Z przełomu II i III wieku pochodzi ważne świadectwo obecności chrześcijan na tym terenie, jakim jest znaleziona w 1839 r. na tutejszym cmentarzu St. Peter l'Estrier grecka inskrypcja Pektoriusza, poświadczająca znajomość prawd wiary (boskość Chrystusa, transsubstancjacja), od-

${ }^{2}$ Por. Tacitus, Annales III 43, 1.

${ }^{3}$ Pro. Pro restituendis scholis oratio, w: Panegyrici Latini IX, wyd. E. Baehrens, Leipzig 1911.

4 Por. anonimową mowę z 312 r. Gratiarum actio Constantino Augusto, w: Panegyrici Latini VIII, wyd. E. Baehrens, Leipzig 1911.

${ }^{5}$ Por. H. de Fontenay - A. de Charmasse, Autun et se monuments, Autun 1889, p. LIV nn. 
mawianie modlitwy za zmarłych i stosowanie sakramentów (chrzest, Eucharystia) ${ }^{6}$. Pierwszym znanym $z$ tradycji biskupem Autun miał być św. Amator, zajmujący stolicę biskupią prawdopodobnie ok. 250 r., a następnym św. Retycjusz, którego wspomina św. Hieronim (De viris illustribus 82) jako autora pisma Przeciwko Nowacjanowi i komentarza do Pieśni nad pieśniami ${ }^{7}$, a Grzegorz z Tours w dziele De gloria confessorum przytacza opis niezwykłego cudu ${ }^{8}$, jaki miał się wydarzyć w chwili śmierci tego świętego (ok. 334): Retycjusz był pierwotnie żonaty, a w chwili śmierci żony złożył przyrzeczenie, że każe się pochować u jej boku; potem jednak został wybrany biskupem Augustodunum. Kiedy umarł, jego ciało zostało zaniesione do rodzinnego grobowca, ku zaskoczeniu obecnych nie można było jednak ruszyć z miejsca mar żony, aż nie przypomniano sobie o ślubie uczynionym niegdyś przez zmarłego. Retycjusz w cudowny sposób przebudził się, aby potwierdzić swoje przyrzeczenie, a zmarla żona ustąpiła mu miejsca u swego boku. Historia ta wykazuje niezwykłe zbieżności z prezentowanym poniżej utworem, stąd w XVIII wieku w środowisku benedyktyńskim klasztoru św. Maura panowało przekonanie, iż bohaterem Laudes Domini jest tenże św. Retycjusz ${ }^{9}$. Pomijając jednak nawet rozbieżności występujące $w$ opisie obu sytuacji, trudno zakładać, że w okresie, kiedy chrześcijaństwo było już co najmniej religio licita, autor utworu przemilczałby imię świętego, należałoby raczej oczekiwać, iż wykorzysta je dla celów pobożnościowych ${ }^{10}$.

Badacze nie znaleźli, jako dotąd, konkretnego wzorca Laudes Domini, dopatrywali się natomiast, prócz wpływów twórczości retorycznej z epoki, także nawiązania do trójdzielnej struktury ówczesnych kazań, składających się z podawanego na początku dla zbudowania słuchaczy przykładu (exemplum), interpretacji i końcowej modlitwy. Autor wychodzi od pytania, niewątpliwie żywego wśród pierwotnych chrześcijan i odżywającego na nowo także w wiekach późniejszych: kiedy nastąpi powtórne przyjście Chrystusa? Próbą odpowiedzi na to pytanie ma być opis cudu, do jakiego doszło w kraju Eduów, kiedy to zmarła chrześcijanka pochowana w rodzinnym grobowcu uniosła dłoń na powitanie ciała zmarłego męża, składanego tam w długi czas potem (ww. 1-35), co ma być dowodem szybkiego nadejścia Chrystusa. Tu następuje główna część poematu - długi ustęp (ww. 33-142) zawierający pochwały na cześć Chrystusa, jako sprawcy cudów, zapowiadanego przez biblijnych Proro-

${ }^{6}$ H. Leclercq, DACL I $3189-3216$ (s.v. Autun; O. Pohl, Das Ichthys Monument von Autun, Berlin 1880; W.B. Marriott, Testimony of the Catacombs, London 1870; H de Fontenay - A. De Charmasse, Autun et se monuments, s. 255nn.

7 Por. J.M. Szymusiak, SWP 344; P. van der Weijden, Laudes Domini, s. 17.

8 Por. De gloria confessorum 75, MGH SRerMer I 2, 343n.

9 Por. Histoire literaire de la France, par des religieux Benedictins de la Congregation de $S$. Maur, I/2, Paris 1733, 95nn.

${ }^{10}$ Por. P. van der Weijden, Laudes Domini, s. 17-18 
ków (w. 36), który u boku Ojca stworzył świat i ofiarował ludziom rozmaite dary. Autor sławi potęgę i lagodność Stwórcy, Jego mądrość, wyrażoną w ukształtowaniu wód (ww. 39-41), ziemi wraz z zamieszkującymi ją zwierzętami (ww. 42-51), rzek i mórz (ww. 52-55), nieba z gwiazdami (ww. 55-60), morzem w jego ustalonych granicach (ww. 61-68), ziemią ze wzgórzami i lasami (ww. 69-76), porami roku (ww. 77-80), dobą z podziałem na dzień i noc (ww. 81-82), ziołami leczniczymi (ww. 83-85) i innymi, niezwykłymi cudami (ww. 8688), a jako zesłany przez Ojca Odkupiciel świata kieruje się nawet ku Piekłu, z którego wyprowadził On dusze sprawiedliwych narodzonych przed swoim przyjściem po to, by nie cierpieli niewinnie, w czym można upatrywać swoistej teologicznej reinterpretacji rzymskiej zasady prawnej lex retro non agit (ww. 128-134). Pan okazuje miłosierdzie także duszom ludzi zmarłych gwałtowną śmiercią, dzięki czemu nie ma ich w swej mocy Szatan, lecz trwają one zawieszone między niebem a ziemią (ww. 137-142). W zakończeniu (ww. 143-148) autor sławi cesarza Konstantyna Wielkiego i jego potomstwo tj. Kryspusa (ur. 307), Konstantyna II i Konstansa (ur. 317). Ponieważ w utworze nie ma aluzji do ostatecznego zwycięstwa Konstantyna nad Licyniuszem w r. 324, pozwala to w przybliżeniu datować utwór na okres między 317 a 323 rokiem ${ }^{11}$.

Biorąc pod uwagę czystość metryczną utworu oraz ciekawe opracowanie tematu współcześni badacze stawiali autorowi dość duże wymagania, co prowadziło do nadmiernego krytycyzmu w odniesieniu do autentyczności niektórych wersów. Według holenderskiego badacza P. Van der Wijdena należy przyjąć, że w zasadniczym swym zrębie utwór jest autentyczny, a przypisywane mu wcześniej niekonsekwencje i miejsca zepsute nie świadczą, jak sądzili dawniejsi wydawcy, o dokonywaniu w nim przeróbek. Trudność, z jaką mamy do czynienia w przypadku Laudes Domini, stanowić może natomiast przekazane w rękopisie następstwo wersów, które bywa zmieniane przez poszczególnych filologów. Dotyczy to zwłaszcza części drugiej, w której autor stara się podkreślić na różne sposoby wszechmoc Pana. Czyni to jednak przy pomocy ograniczonych środków stylistycznych, sięgając wielokrotnie po analogiczne struktury $^{12}$. Często posługuje się aliteracją, anaforą, antytezą, grą słów. Świadectwem epoki powstania poematu są natomiast tzw. rymy leonińskie, których doliczono się 23.

Dzieło zachowało się w jednym jedynym rękopisie z IX wieku, przechowywanym pierwotnie $\mathrm{w}$ klasztorze św. Juliana $\mathrm{w}$ Tours, znanym następnie jako Colbertinus 4133, a później Regius 6411.5. Obecnie znajduje się w zbiorach francuskiej Bibliothèque Nationale jako Codex Parisinus Latinus 7558, ff. $111 \mathrm{v}$. - 114v. Widoczne są na nim poprawki dokonane prawdopodobnie w okresie

${ }^{11}$ Por. tamże, s. 16-20.

12 Por. M. Cytowska - H. Szelest, Literatura rzymska. Okres cesarstwa. Autorzy chrzescijańscy, Warszawa 1994, 194. 
powstania rękopisu (tzw. Manus secunda) oraz znacznie późniejsze (manus tertia), wprowadzone prawdopodobnie przez autora editio princeps wydanej w 1560 r. w Paryżu, G. Morela. Za jedną z lepszych edycji, poza P. van der Weijdenem, uważa się wydanie W. Brandesa (zob. bibliografia).

\section{WYDANIA TEKSTU}

G. Morel, Cl. Marii Victoris oratoris Massiliensis, A $\Lambda H \Theta E I A \Sigma$, seu commentationum in Genesin lib. III. Epigrammata Varia vetusti cuiusdam auctoris, inter quae sunt et aliquot psalmi versibus redditi. Hilarii Pictaviensis episc. Genesis, Cypriani, Genesis et Sodoma. Dracontii, De opere sex dierum. Omnia versibus, nunc primum e vetustis codicibus expressa, Parisiis 1560, 85-90.

G. Fabricius, Poetarum veterum ecclesiasticorum opera christiana, et operum reliquiae atque fragmenta, Thesaurus catholicae et orthodoxae ecclesiae, et antiquitatis religiosae, ad utilitatem iuventutis scholasticae, collectus, emendatus, digestus, et commentario quoque expositus, Basileae 1564.

A. Rivinus, De Christo Jesu, beneficiis et laudibus eius, aliquot Christianae reliquiae veterum poetarum ecclesiasticorum etc. etc., Lipsiae 1652.

Maxima Bibliotheca veterum Patrum, et antiquorum scriptorum ecclesiasticorum XXVII, Lugduni 1677, 527-528.

Collectio Pisaurensis omnium poematum, carminum, fragmentorum latinorum, sive ad christianos, sive ad ethnicos, sive ad certos, sive ad incertos poetas, a prima latinae linguae aetate ad sextum usque christianum seculum et Longobardorum in Italiam adventum pertinens, ab omnium Poetarum Libris, Collectionibus, Lapidibus, Codicibus exscripta, VI christianos poetas continens, Pisauri 1766, 249-250.

F. Arevalo, C. Vettii Aquilini Iuvenci presbyteri hispani Historiae Evangelicae libri IV. Eiusdem carmina dubia, aut suppositicia, Romae 1792, Appendix II: Iuvenci sive auctoris incerti carmen De Laudibus Domini, 448-455.

J.P. Migne, Patrologiae cursus completus, Series Prima, Patres Latini, Parisiis, t. 6 (1844) 45-50; t. 19 (1846) 379-386 (= ed. Arevalo); t. 61 (1847) 1091-1094.

W. Brandes, Ueber das frühchristliche Gedicht "Laudes Domini". Nebst einem Excurse: die Zerstörung von Autun unter Claudius II, Braunschweig 1887, 5-10.

P. Van Der Weijden, Laudes Domini. Tekst, vertaling en commentaar, Amsterdam 1967.

A. Salzano, Laudes Domini. Introduzione, testo, traduzione e commento, Napoli 2000.

\section{BIBLIOGRAFIA}

B. Altaner - A. Stuiber, Patrologia, thum. P. Pachciarek, Warszawa 1990, 531;

O. Bardenhewer, Geschichte der altkirchlichen Literatur, III, Freiburg 1923, 428429; G. Bardy, Littérature latine chrétienne, Paris 1929, 119; tenże, Les „Laudes Domini". Poème autunois du commencement du IV siècle, "Mémoires de 
l'Academie des sciences, arts et belles-lettres de Dijon" (1933) 36-51; A. di Berardino - J.Quasten (re.), Patrologia, III: I padri latini (secoli IV-V), Torino 1992, 315316; W. Brandes, Uber das frühchristliche Gedicht "Laudes Domini”. Nebst einem Excurse: Die Zerstörung von Autun unter Claudius II. Wissenschaftliche Beilage zu dem Programm des Herzoglichen Gymnasium Martino-Catharineum in Braunschweig Ostern, Braunschweig 1887; M. Cerretani, Il poemetto anonimo „Laudes Domini", diss., Perugia 1984; M. Cytowska - H. Szelest, Literatura rzymska. Okres cesarstwa. Autorzy chrześcijańscy, Warszawa 1994; A. Dihle, Die griechische und lateinische Literatur der Kaiserzeit. Von Augustus bis Justinian, München 1989, 408; J. Fontaine, Naissance de la poésie dans l'Occident chrétien, Paris 1981, 101-102; A. Frisone, Sancti poetae, „Helikon” 9-10 (1969) 673-676; H. de Fontenay, Autun et ses monuments, avec un precis historique par A. de Charmasse, Autun 1889; B. Gladysz, Konstantyn Wielki w poezji swoich czasów, CT 18 (1937) 63-98; A. Harnack, Geschichte der altchristlichen Litteratur bis Eusebius, II/2, Leipzig 1904, 138 i 449-450; R. Herzog, Handbuch der lateinischen Literatur der Antike, Bd. IV: Restauration und Erneuerung. Die lateinische Literatur 284-374, München 1989, 330-331; O. Hirschfeld, Die Haeduer und Arverner unter Romischer Herrschaft, w: Sitzungsber. der Preuss. Ak. der Wissensch. zu Berlin, Berlin 1897, 1099-1119; W. Kirsch, Die lateinische Versepik des 4. Jahrhunderts, Berlin 1989, 79; J. Opelt, Das Carmen „De laudibus Domini” als Zeugnis des Christentums bei den Galliern, „Romano-barbarica" 3 (1978) 159-166; R. Peiper, Bemerkungen zu dem frühchristlichen Gedichte Laudes Domini, ,Zeitschrift für die Österreichischen Gymnasien” 41 (1890) 106109; M. Schanz, Geschichte der römischen Litteratur bis zum Gesetzgebungswerk des Kaisers Justynian IV/1, München 19594, 206-207; Słowniki: ECat VII 957 (E. Peterson); LThK 2 VI 354 (J. Martin); SWP 260 (J. Szymusiak); DPAC II 1908-1909 (A di Berardino); EK X 565 (M. Szram).

\section{PRZEKEAD*}

Quis queritur sera virtutes dote iuvari? Quis promissa Dei lento procedere passu? Quis fine humano metitur iudicis urnam perpetui tardumque putat, quod saecula debent? Accelerare diem, meritis qui praemia reddat, nobilis ingenti testatur gloria facto.
Kto może się uskarżać, że cnót ${ }^{1}$ nagrodą zbyt późno się cieszy? Kto, ze zbyt wolno nadchodza obietnice Boże? ${ }^{2}$ Kto ludzką miarą ${ }^{3}$ mierzył będzie urnę Wiecznego Sędzi i uzna za powolne, na co wieków trzeba. Ze dzień ten blisko, który nagrodzi zasługi ${ }^{4}$, swiadczy niezwykla sława wielkiego zdarzenia

* Przekladu dokonano na podstawie wydania krytycznego P. Van der Weijdena, Laudes Domini. Tekst, vertaling en commentar, Amsterdam 1967. Na nim też oparta jest większość przypisów.

1 Występujące w oryg. określenie virtutes może oznaczać także dobre uczynki.

${ }^{2}$ Utwór rozpoczyna się potrójną retoryczną anaforą: quis ..., quis ..., quis.

${ }^{3} \mathrm{~W}$ oryg. fine $=$ modo, określenie występujące $\mathrm{w}$ tym znaczeniu m.in. u Cycerona, Lukrecjusza i Horacego.

${ }^{4}$ Por. Mt 16, 27: „Albowiem Syn Człowieczy przyjdzie w chwale Ojca swego razem $z$ aniołami swoimi, i wtedy odda każdemu według jego postępowania"; Juvencus, Evangeliorum IV 303: „meritis sua praemia reddit". 
nam qua stagnanti praelabitur agmine ripas tardus Arar pigrumque diu vix explicat amnem qua fraterna Remo progignitur Aedua pubes, coniugium memini summa pietate fideque; lex divina tamen meritum cumulabat amoris. Et votum ambobus socium praecedere morte, maerorique pio curam mandare sepuicri. Sed prior uxorem decreti pagina legit ${ }^{i l}$ Tum desolatus largo iubet ore cavari, post mortem fiunt quae membris hospita saxa; susciper<e $>$ et veniens aeternaque foedera iungens, ut, quos viventes tenuisset lectulus idem, post praecepta Dei bustum commune levaret. Sensit vota sui coniunx praesaga mariti magnaque temporibus tribuit miracula castis. Nam cum defunctis iungantur brachia membris et repetita manus constringant vincula trunco,
Tam bowiem, gdzie wolnym nurtem ${ }^{5}$ obmywa wybrzeża Niespieszny Arar, $z$ trudem tocząc swe leniwe wody, tam gdzie z Remusem zbratana Eduuów ${ }^{6}$ młódź wzrasta, wspomnę ${ }^{7}$ malzeństwo wielkie uczuciem i zaufaniem ${ }^{8}$, którego miłości zasługę wieńczy Boskie Prawo.

$\mathbf{Z}$ tych dwojga każde ślubowało zgonem ${ }^{9}$ uprzedzić małżonka, troskę o grób zlecając temu, k to przeżyje ${ }^{10}$.

Żonę zaś pierwszą wskazala Księga Przeznaczenia; wówczas mąż opuszczony wejście wydrążyć nakazał w skałach, które po śmierci chętnie przyjmą jego czlonki. A kiedy przyszedł wiecznym związać się przymierzem ${ }^{12}$, by tych, co za życia jedno lączyło posłanic, ${ }^{13}$ zrządzeniem Boskim wspólny przyjąl grób, przeczuła mądra zona śluby swego męża, w nagrodę dając cuda za życie w czystości ${ }^{14}$. Gdy bowiem ze zmartymi czlonkami zlączono ramiona, więzy zaś wielokrotnie lączą ręce $\mathrm{z}$ ciałem ${ }^{15}$,

${ }^{5} \mathrm{~W}$ oryg.: ,stagnanti praelabitur agmine ripas tardus Arar pigrumque diu vix explicat amnem”, por. Juvencus, Evangeliorum III 461: „Agmine Iordanis viridis perrumpit amoeno”. Powolność nurtu Araru (dzisiejsza Saona) była w starożytności przystowiowa, por. Caesar, De bello Gallico I 12: „Flumen est Arar, quod per fines Aeduorum et Sequanorum in Rhodanum influit incredibili lenitate, ita ut oculis, in utram partem fluat, iudicari non possit"; Plinius, Naturalis historia III 4: „segnis Arar”; Silius Italicus XV 504: „Quorum serpit Arar per rura pigerrimus undae"; Klaudianus, De Consul. Mall. Theodori 53: "tardus Arar”; In Rufinum II 111: „Quos Rhodanus velox, Araris quos tardior ambit”; Juvencus, Evangeliorum III 461: „Agmine Iordanis viridis perrumpit amoeno".

6 W oryg. „Qua fraterna Remo progignitur Aedua pubes”. Eduowie (lac. Aedui, Hedui, Edui), zostali uznani przez senat rzymski za sprzymierzeńców obdarzanych mianem braci i krewniaków (fratres et consanguinei), por. Caesar, De bello Gallico I 33; Cicero, Ad Atticum ep. I 16 (19).

7 Występujące w oryg. określenie memini - „pamiętam, mam w pamięci”, może wskazywać także na to, iż piszący znal osobiście wspominane postaci.

${ }^{8} \mathrm{~W}$ oryg. "pietate fideque" - pojęcia, które, jak wynika z wersu następującego, nie mają charakteru chrześcijańskiego (pobożność, wierność), lecz odnoszą się do świata starorzymskich pojęć związanych z wzajemnym poszanowaniem małżonków.

${ }^{9}$ Por. formulę często występującą w starochrześcijarískich inskrypcjach nagrobnych: „,contra votum superstes".

${ }^{10}$ Dosł. „mareori pio" - smutkowi będącemu oznaką miłości [ze strony tego z malżonków, który pozostanie przy życiu].

$11 \mathrm{~W}$ oryg. legit $=$ delegit.

${ }^{12}$ W oryg. „susciper et veniens aeternaque foedera iungens”, koniektura D. Kuijpera przyjęta przez P. van der Wijdena w jego wydaniu tekstu, por. Laudes Domini, s. 72; sens: złożone za życia ślubowanie małżeńskie ma zostać przypieczętowane także po śmierci; zob. Vergilius, Aeneis XI 356: „aeterno foedere iungens”.

${ }^{13}$ Por. Ovidius, Metamorphoses IV 154 (opowieść o Pyramie i Tyzbe): „estote rogati [...] ut quos certus amor, quos hora novissima iunxit, componi tumulo non invideatis eodem".

${ }^{14}$ Chodzi o niezawieranie powtórnego związku małżeńskiego przez owdowiałego malżonka, wysoko cenione przez chrześcijan pierwszych wieków na Zachodzie, por. A.G. Hamman, Życie codzienne pierwszych chrześcijan (95-197), Warszawa 1990, 200.

${ }^{15}$ Por. Juvencus, Evangeliorum IV 395. 
ne, quibus humanae complentur munera vitae, accidat informis fluitatio dissociatis,

immensum dictu!: quo tempore vita peracta est iungendus sociae <et> prospecta sede maritus, postquam morte viri reserata est ianua leti horrendumque larem iam lux ingrata retexit, deprensa est laevam protendens femina palmam, invitans socium gestu viventis amoris.

Quis dedit affectum tumulo? quis vincula solvit? unde sepulta videt venturam coniugis umbram? Tu facis haec, tu Christe Deus, tua signa moventur, paulatimque doces sopita resurgere membra. tu, quem venturum sancti cecinere prophetae, incorrupta Dei soboles, rectorque regentis, quo sine nil magnum, genitor deliberat ingens, cuius ad imperium certis mare constitit oris - nec licet immenso terris excurrere ponto! planaque montanos includunt littora fluctus; qui vario stabilem dotasti munere terram, in nostros usus, largus pietate paterna. te vade mortales committunt semina sulcis, Et novus arenti procedit caespite partus; tu manare iubes fecundo nectare vites, aby członki ${ }^{16}$ za życia pełniące swa rolę rozdzielone nie poszły $w$ bezksztaltną rozsypkę, (rzecz nie do opisania!), gdy życie osiągnęlo kres, a mąż mial zejść się z żoną w wyznaczonym miejscu i gdy po śmierci męża otwarto drzwi grobu, straszliwe zaś domostwo ${ }^{17}$ zalal niemily mu blask, ujrzano, jak żona lewą wyciągając dłon ${ }^{18}$, gestem wita towarzysza doczesnej milości.

Któz dał zmysły grobowi? Kto rozwiazat pęta? Jak zmarła widzieć może wchodzący cień męża? Ty sprawiasz to, Ty, Chryste - Boże, wznosisz swoje znaki ${ }^{19}$ I stopniowo pouczasz, jak wznoszą się uśpione czlonki ${ }^{20}$, Ty, którego nadejście wieszczyli czcigodni prorocy ${ }^{21}$, Nieśmiertelny potomku Boga, rządco tej, co rządzi ${ }^{22}$, bez którego potężny Rodzic nie zamyśla niczego wielkiego ${ }^{23}$ i którego rozkazem morze trzyma się swych brzegów, a toń niezmierna nie może rozlać się na lądy ${ }^{24}$, plaskie zaś brzegi powstrzymują gigantyczne fale ${ }^{25}$. Ty, który wielorakim darem suchy obdarzyles ląd dla naszych potrzeb, szczodry w ojcowskiej miłosci.

Tyś rękojmią śmiertelnych, gdy ziarno powierzają bruzdom ${ }^{26}$, I nowy plon kiełkuje ze spragnionej ziemi,

Ty winorośli każesz spływać obfitym nektarem ${ }^{27}$,

${ }^{16}$ Por. Julianus Toletanus, Prognosticum I 18: „Non tamen contemnenda, et abiicienda sunt corpora defunctorum, maximeque iustorum, atque fidelium, quibus tamquam organis, et vasis ad omnia bona opera, et sancta usus est Sanctus Spiritus".

${ }^{17}$ W oryg. „lar”, określenie starorzymskiego bóstwa ogniska domowego, które stało się $\mathrm{z}$ czasem synonimem domu.

${ }^{18} \mathrm{~W}$ oryg. „laevam protendens [...] palmam"; lewa strona uchodzila w tradycji rzymskiej za szczęśliwą, m.in. pojawienie się podczas wróżb ptaków po lewej, wschodniej stronie nieba uznawano za pomyślny znak, por. L. Winniczuk, Ludzie, zwyczaje i obyczaje starożytnej Grecji i Rzymu, Warszawa 1983, 689.

${ }^{19}$ W oryg. „signa moventur”, być może należy lączyć to sformułowanie z wojskowym „signa movere", oznaczającym wyruszenie oddziału z miejsca postoju.

20 Tzn. na przykładzie poruszenia konkretnej zmarłej pouczasz nas o przyszłym wskrzeszeniu umarłych „spiących" dotychczas w oczekiwaniu na zmartwychwstanie ciał; por. $1 \mathrm{Kor} 15,52$.

${ }^{21}$ Iz 40, 10 i Dn 7, 13; por. Juvencus, Evangeliorum II 104: „quem voces veterum et sancti cecinere prophetae". W tym miejscu rozpoczyna się właściwy wątek utworu, tj. pochwały na cześc Pana.

${ }^{22}$ W oryg. ,incorruptibilis" - nie podlegający zniszczeniu (gr. ă $\left.\phi \theta \alpha \varrho \tau o \zeta\right)$ Chrystus jest tu przedstawiony jako zwycięzca wszechwładnej dotąd śmierci: „rector regentis” [sc. mortis].

${ }^{23}$ Por. Vergilius, Georgica III 42 (w odniesieniu do Mecenasa): „te sine nil altum mens incohat".

${ }^{24}$ Wers ten jest przez B. Brandesa uważany za poźniejsze wtrącenie, podobnie jak ww. 42-55, inaczej inni badacze, por. P. van der Weijden, Laudes Domini, s. 95-96.

${ }^{25} \mathrm{~W}$ oryg. "planaque montanos includunt littora fluctus", por. Vergilius, Ecloga IX 43: „insani feriant sine litora fluctus”; Aneis II 305-306: „aut rapidus montano flumine torrens sternit agros".

${ }^{26} \mathrm{~W}$ oryg ,te vade mortales committunt semina sulcis”, por. Vergilius, Georgica I 223: „debita [...] sulcis committas semina”; II 289: „ausim vel tenui vitem committere sulco". 
Tu gratos epulis hominum medicosque saluti arboribus succos, tu nobis dulcia mella; Tu servire iubes homini genus omne animantum. insuper et gravibus lucos curvescere pomis atque novos reditus nullo de semine nasci; tu varios amnes nostro prodesse labori et renovare sacris benedictum fontibus aevum te duce velivolis patuerunt aequora rostris divisosque fretis lustravit navita portus. Tu postquam certis sunt acta elementa figuris, ne torpere rudi caelestis machina vultu inciperet, vario signasti lumine mundum et quicquid caelo radiat, tua dextera finxit; his aulam Domini placuit contexere ditis. Iam freta ne nullis agerentur inhospita terris assiduumque alacer muneraret navita portum, crebra satis tumido defigitur insula ponto, - nec tamen insano metuit circumdata fluctu exiguoque fretis innitens orbe resistit, te duce confidens, cuius venerabile pactum nexum lege pari summumque imumque peraequat, nec sinit impositos quoquam transcendere fines. Ac ne plana nimis tellus vel nuda iaceret, vitibus aptandos iussisti assurgere colles grandibus, et largos umbracula texere lucos; tum ne vastus agat silvis torpentibus horror innumeros foetus proceris saltibus addis, incola vel nemori neu desit praeda petenti; tum voluctes multas et mille examina vocum, mortali harmonia lucis resonare canoris; drzewom soki wylewac, miłe ucztującym, zbawienne dla ich zdrowia, slodkie dla nas miody; Ty slużyć nakazujesz wszelkim typom zwierzą ${ }^{28}$, sadom zas zginać karki pod ciężarem jablek ${ }^{29}$ a nowym plonom rodzić się bez żadnych nasion ${ }^{30}$. Ty rzekom rozkazaleś wspierać nasze trudy ${ }^{31}$ i świat ochrzczony ${ }^{32}$ odnawiać świętymi wodami. Za Twym przewodem morza otwarly się żaglom, a żeglarz porty jął odwiedzać rozdzielone morzem. Ty, skoro elementy przybrały określoną postać, aby wszechświat ${ }^{33}$ nie zastygl z pierwotnym obliczem, różnym rodzajem światła ozdobileś niebo ${ }^{34}$.

I cokolwiek na niebie błyszczy, twoja osadzila ręka. Tym bogactwem zechciales pokryć dwór niebieski ${ }^{35}$, by niegościnne morza nie były pozbawione wysp, a śmialy żeglarz zyskal upragniony port, dość gęsto wyspy osadzasz na wzburzonym morzu, nie trwożą się jednak, dziką otoczone falą, lecz opierając się morzu trwają na szczupłym obszarze, ufne w Twoje przywództwo, 2 którym święty pakt ${ }^{36}$ zawarty, jednako zrównuje wysokosć i glębię i nie pozwala nijak przekroczyć ustalonych granic. Po to zaś, by ziemia nie była zbyt pusta lub naga, pagórkom wznieść się kazałeś stworzonym dla wina ${ }^{37}$ i obszernym gajom osłonić się cieniem.

Aby zaś lęk nie ogarniał wśród milczących lasów, niezliczone potomstwo dajesz smukłym gajom, by myśliwemu w lesie nie brakło zwierza ni zdobyczy; liczne też ptaki dodajesz, wielką chmarę glosów, by $w$ gajach rozbrzmiewały zgodnym ziemskim śpiewem ${ }^{38}$.

27 W oryg. tu manare iubes fecundo nectare vites, por. Vergilius, Georgica IV 384: ter liquido ardentem perfundit nectare Vestam.

${ }^{28}$ Aluzja do $\mathrm{Rdz} 1,26$; por. Lucretius, De rerum natura I 4: genus omne animantum.

$29 \mathrm{~W}$ oryg. gravibus lucos curvescere pomis, por. Ambrosius, Expositio Psalmi CXVIII 6, 26: "[vinea] fructu curvescit uvarum".

30 Por. obraz przyrody kierowanej ręką Wenus u Lukrecjusza, De rerum natura I 1-23, a także opis zlotego wieku kiedy wszystko rodziło się „samo z siebie” u Owidiusza, Metamorphoses I 89-110.

${ }^{31}$ Por. Vergilius, Aeneis IX 404.

32 W oryg. „et renovare sacris benedictum [sc. a Ioanne Baptista]”, por. Juvencus, Evangeliorum II 193: „liquido si quis de fonte renatus”.

33 W oryg. ,machina caelestis".

34 Tu określenie "mundus" w znaczeniu nieba - „caelum".

35 W oryg. „his aulam Domini placuit contexere ditis”, por. Juvencus, Evangeliorum III 437 438: „nam caeli regnum domini praedivitis aulae consimile est".

36 W oryg. „venerabile pactum" - prawdopodobnie aluzja do przymierza Boga z ludźmi opisanego w Rdz 9, 9.

37 W oryg. „vitibus aptandos iussisti assurgere colles”, por. Vergilius, Ecloga IX 42: ,et lentae texunt umbracula vites"; Hilarius Pictaviensis, In Genesim 107: „[vitis] pampineas celsis texebat collibus umbras".

${ }^{38}$ W oryg. „mortali harmonia lucis resonare canoris”, por. Vergilius, Georgica II 328: „avia tum resonant avibus virgulta canoris". 
sic annum placuit variis intexere formis et vice iucunda mortalibus addere fructum, neu semper prolixa dies nimis ureret orbem neve brevis iustum raperet nascentibus ignem, Ac ne perpetuo quateret labor omnia nisu, dat requiem fessis hominum nox roscida curis; utque humana salus securum duceret aevum, sponte salutares de caespite surgitis herbae; has pater ipse serit nutu, non vomere dives. Non ego, ferrato tegerer si viscera muro ferrea vox linguaeque forent mihi mille canenti, munera cuncta queam vestrae pietatis obire. Sed pater ille tuus, secreta in sede locatus, nec cuiquam visu facilis, cunctisque tremendus, te misit dominum terris vitaeque magistrum. et quisquis natum iusto veneratur honore, ambobus sua vota dicat vitamque perennem tu casti rectique tenax, et flectere leges post crimen facilis, si quem vecordia praeceps depulit a vobis praescripto limite vitae. te genitor nostra, paterentur ut ora tueri, induit humana facie membrisque caducis; quis temptaret enim fragiles attollere visus, si talis trepidis voluisses sistere terris, qualis es, ingenti cum torques fulmina dextra praesentemque iubes directa pavescere poenam
Rok przyodziać zechciałeś rozmaitym kształtem i w milej porze roku ludziom dać owoce. Po to, by wciąż dzień dhugi ziemi nadmiernie nie palil, ani tez zbyt krótki dobrego roślinom nie zabieral ciepła, znój zaś nie dręczyl wszystkiego nieustannym jarzmem noc $z$ rosą ${ }^{39}$ daje wytchnienie ludziom zmęczonym od trosk. Aby zaś zdrowa ludzkość spokojne mogła wieść życie ${ }^{40}$ same przez się wzrastacie, zbawienne zioła, $z$ tej ziemi, Ojciec swą wolą je sieje, lemieszem nie orze bogaty. $\mathrm{Ja}$, choćbym murem żelaznym otoczyl moje wnętrzności, choćbym żelazny mial glos ${ }^{41}$ i śpiewal tysiącem języków, Nie mógłbym wszystkich darów waszej miłości wyrazić. A sławny ów Ojciec Twój, żyjący w ukrytej siedzibie ${ }^{42}$ i niewidzialny dla wszystkich ${ }^{43}$, we wszystkich bojaźn budzący, zesłal Ciebie, ziem Pana i Mistrza dobrego żyota. Każdy, kto daje Synowi czesć w sposób Jemu należny, Obu Wam śluby składa i zycie poświęca wieczne ${ }^{44}$. Ty, który trzymasz się tego, co czyste i sprawiedliwe ${ }^{45}$, grzech łatwo skłonny wybaczać, gdy zaślepione szaleństwo człowieka spycha ze szlaku wam wskazanego życia. Tobie, by nasze oczy mogły Cię jasno dostrzegac $c^{46}$, Ojciec ludzką dal twarz ${ }^{47}$ i w słabe przyodzial członki ${ }^{48}$. Któżby się bowiem powazyl słabe swe oczy podnosic ${ }^{49}$, Gdybyś na drżącej ziemi taki jak wtedy chcial stanąć, kiedy potęzną prawica wypuszczasz swe blyskawice ${ }^{50}$ i każesz lękać się kary, która natychmiast nadchodzi,

${ }^{39} \mathrm{~W}$ oryg. nox roscida, por. Plinius, Historia naturalis II 62, 153: „roscidas aestate Africae noctes"; XVIII 28, 260: „noctibus roscidis secari melius".

${ }^{40}$ W oryg. "utque humana salus securum duceret aevum", por. Horatius, Satyrae I 5, 101: „namque deos didici securum agere aevum".

${ }^{41}$ W oryg. ,ferrea vox linguaeque forent mihi mille canenti, munera cuncta queam vestrae pietatis obire”, por. Vergilius, Aeneis VI 625: "non, mihi si linguae centum sint oraque centum, ferrea vox, omnis scelerum comprendere formas, omnia poenarum percurrere nomina possim"; Georgica II 42nn.: "non ego cuncta meis amplecti versibus opto, non, mihi si linguae centum sint oraque centum, ferrea vox".

${ }^{42}$ W oryg. "secreta in sede locatus", por. Vergilius, Aeneis II 568: „secreta in sede latentem".

${ }^{43}$ W oryg. ,nec cuiquam visu facilis”, por. Vergilius, Aeneis III 621: „nec visu facilis nec dictu adfabilis ulli".

${ }^{44}$ Po tym wersie występuje w zachowanym rękopisie nieco większy odstęp, co nasunęlo niektórym badaczom przypuszczenie o opuszczeniu jakiejś partii oryginalnego tekstu, por. P. van der Weijden, Laudes Domini, s. 140.

${ }^{45}$ W oryg. „tu casti rectique tenax”, por. Vergilius, Aeneis IV 188: „[fama] tam ficti pravique tenax".

${ }^{46}$ W oryg. ,paterentur ut ora tueri”, por. Vergilius, Aeneis VI 688-689: „datur ora tueri, nate, tua".

47 W oryg. ,induit humana facie”, por. Ovidius, Metamorphoses II 425: ,protinus induitur faciem cultumque Dianae"; II 850: „induitur faciem tauri”.

48 W oryg. „induit [...] membrisque caducis”; por. Cicero, De natura deorum I 35, 98: „corpore caduco et infirmo"; Paulinus Nolanus, Carmina VI 21: „conferre aeterna caducis”.

49 W oryg. „fragiles attollere visus”, por. Vergilius, Aeneis IV 688: „illa grauis oculos conata attollere rursus deficit". 
vel cum placatus campis sitientibus imbres dividis, et dubias sulcis producis aristas. ne tamen insignem res nulla ostenderet ortum, virgine conciperis, - non sufficit esse pudicam nec quae nupta queat domino coniungere fratrem ut procul ex utero contagio turpis abesset. Mox ubi processu felix maturuit aetas, indociles animos monitis servare paternis aggrederis, rectamque viam labentibus offers; atque ut missa deo penitus praecepta paterent, imperium morti adimis morboque solutos desperata iubes apprendere munia vitae restituisque diem caecis et, ne quid inausum restaret penitus, quo perfidus error obiret, indicis sensum tumulis, et condita pridem membra iubes iterum superas consurgere in auras, agnoscuntque suum dilecta cadavera nomen. At postquam legem sectator idoneus hausit, ut se mortali coelestis spiritus aula exueret, legis intentum quo cuncta doceret pro summo toleranda Deo, recteque perennem contemptu mortis sibi quemque assumere vitam. Sic completa ferens genitoris iussa, redisti ad summi secreta poli, qua lucidus aether pigra vetat proprio succedere nubila coelo: atque ut certa foret pereuntis copia turbae quae praecepta dei miserandis auribus arcet, nec nova defunctos iam pridem iura tenerent, albo gdy, ublagany, deszczów polom spragnionym udzielasz, $z$ bruzd dobywając wbrew spodziewaniu klosy. By jednak rzecz niepoślednia dowiodła wielkości narodzin poczạłeś się z Dziewicy, która nie dosyć, że czysta, to, choć zamężna, Panu nie zrodzila brata, tak, że $z$ dala od łona szpetna trzymała się zmaza. Wnet, gdy z czasem dojrzal Twój \$zczęśliwy wiek ${ }^{51}$. jąleś ratować umysły, do Ojca przykazań nieskore i prostą wskazywać drogę tym, co zeszli ze szlaku. Po to zaś, by zesłane przez Boga nakazy calkiem ujawnić władzę śmierci odbierasz, od chorób tych wyzwoliwszy. którzy w swe życie zwątpili - na nowo każesz im życ ${ }^{52}$. Blask dnia ślepym przywracasz, by wypróbować to wszystko ${ }^{53}$, czym można błąd przewrotny zupełnie $z$ dala utrzymać; czucia zmarłym udzielasz, a tym, które wcześniej złożone członkom nakaz wydajesz, by wzniosły się znowu w górę ${ }^{54}$, ciała zaś ukochane mogą rozpoznać swe imię ${ }^{55}$.

A kiedy już Naśladowca ${ }^{56}$ wlaściwie Prawo wypelnil, aby się Duch Niebieski wydostal z śmiertelnej jego siedziby ${ }^{57}$, który, jak czytasz, o wszystkim pouczyć pilnie się starał, co każdy dla Najwyższego znieść musi i jakim sposobem żywot wieczny osiągnie, mając w pogardzie śmierć.

A wypełniwszy nakazy Rodzica wrócileś do szczytu skrytego bieguna ${ }^{58}$, tam gdzie eter swietlisty wzbrania chmurom powolnym wznosić się ku niebu ${ }^{59}$. Po to zas, by określić wielkość tłumu zmarłych. który nędzne uszy zamyka dla przykazań Bożych. a żeby nowe prawa nie wiązaly wcześniej umarlych ${ }^{60}$

${ }^{50}$ W oryg. ,ingenti cum torques fulmina dextra”, por. Vergilius, Aeneis IV 208-209: „an te genitor, cum fulmina torques, nequiquam horremus".

51 W oryg. „Mox ubi processu felix maturuit aetas”, por. Vergilius, Aeneis XII 438: „mox cum matura adoleverit aetas".

52 W oryg. „iubes apprendere munia vitae", por. Horatius, Epistolae II 2, 131: "qui vitae servaret munia".

${ }^{53}$ W oryg. „ne quid inausum”, por. Vergilius, Aeneis VII 308-309: „nil linquere inausum quae potui”; VIII 205-206: „at quid Caci mens effera ne quid inausum aut intractatum scelerisve dolive fuisset".

54 Por. Vergilius, Aeneis VI 128: „sed revocare gradum superasque evadere ad auras”; Juvencus, Evangeliorum IV 322: „carum iuvenem [sc. Lazarum] faciam consurgere rursus".

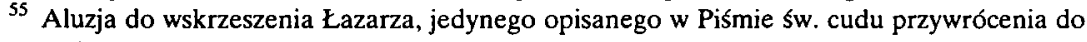
życia zmarłego dokonanego przez Jezusa, por. J 11, 1-44.

56 W oryg. „Sectator”, tzn. Jezus.

57 Tzn. ciala ludzkiego, por. Ambrosius, De Spiritu Sancto I 3, 54: ,quae [sc. Caro Christi] aula virtutis [...] est”. Termin „spiritus” na określenie duszy używany byl już w literaturze przedchrześ-' cijańskiej, por. Vergilius, Aeneis IV 336: „dum spiritus hos regit artus”; Ovidius, Metamorphoses XV 167: „spiritus eque feris humana in corpora transit".

58 W oryg. „summi secreta poli”, por. Juvencus, Evangeliorum I 209-210: „coeli secreta”.

59 Por. Vergilius, Aeneis XII 367: "qua venti incubuere, fugam dant nubila caelo"; Ovidius, Amores I 8: „toto glomerantur nubila caelo".

${ }^{60} \mathrm{~W}$ oryg. „nec nova defunctos iam pridem iura tenerent"; chodzi tu o sprawiedliwych i proroków Starego Testamentu. 
carceris inferni feralia libera solvis innumeramque iubes tenebris emergere plebem his tantum clausis, quos impia vita notarit et loca poenarum venturis dividis umbris, quae tibi non credant vel quae se credere fingant, sancte deus summique dei venerabile pignus. ad cuius nomen violenta morte fugatae pectoribus propriis alienaque pectora nanctae exclamant pallentque animae, iussaeque recedunt (sicut multa prius de te miracula produnt) cum terram caelumque inter suspensa tenentur, obstricto per te quia nil permittitur hosti. At nunc tu dominum meritis, pietate parentem, imperio facilem, vivendi lege magistrum edictisque parem, quae lex tibi condita sanxit, victorem laetumque pares mihi Constantinum! hoc melius fetu terris nil ante dedisti nec dabis: exaequent utinam sua pignora patrem! puszczasz wolno ofiary z piekiel ich więzienia i wielkiej ciżbie wyjść każesz z ciemności, zamknąwszy tylko ludzi z piętnem zlego życia i miejsca kar wydzielasz mającym przyjść cieniom ${ }^{61}$, które w Ciebie nie wierzą lub wiarę udaja, Święty Boże, czcigodny Potomku Najwyższego Boga, na którego imię dusze ${ }^{62}$ wygnane przez gwałtowną śmierć ${ }^{63}$ $z$ własnych piersi, inne napotkawszy ciała wołaja, drża, ustępują pod wpływem nakazu (jak świadczą liczne Twe wcześniejsze cuda), gdy między ziemią a niebem zawieszone tkwią ${ }^{64}$ na Twój rozkaz, niczego nie dając wrogowi ${ }^{65}$. A teraz Ty, władcę dzięki zashugom, rodzica dzięki milości, życzliwego w rządzeniu, mistrza drogi życia, równego uchwałom ${ }^{66}$, które uznalo twe Prawo, Konstantyna $a^{67}$ daj mi ujrzeć radosnym zwycięzcą. Lepszego od niego owocu nie daleś przedtem tej ziemi, ani też nie dasz ${ }^{68}$. Oby potomstwo jego dorównało ojcu!

\section{$\mathrm{Z}$ języka łacińskiego przełożył, wstępem i komentarzem opatrzył Robert Sawa}

${ }^{61}$ W oryg. „umbras” - cienie, termin zapożyczony ze świata wierzeń pogańskich.

${ }^{62}$ W oryg. ,animae" = „daemonia".

${ }^{63}$ Cały ustęp następujący (ww. 137-142) poświęca autor ludziom zmarłym nagle, m.in.

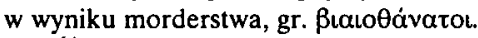

${ }^{64}$ Por. Tertullianus, De anima XXII 8: „omnis spiritus ales est”.

65 W oryg. "hosti" tj. szatanowi, por. Paulinus Nolanus, Natal. XI (S. Felicis) 230nn.

66 W oryg. „edictisque parem"; prawdopodobnie aluzja do edyktu mediolańskiego z 313 roku.

${ }^{67}$ Por. podobną pochwalę Konstantyna u Juwenkusa Evangeliorum IV 806-812.

68 Por. pochwałę Augusta u Horacego, Carmina IV 2, 37-39: „Quo nihil maius, meliusve terris fata donavere, bonique divi nec dabunt, quamvis redeant in aurum tempora priscum". 